\title{
Molecular Detection of Grape Decline Phytoplasma in Leafhopper Species Associated with Infected Grapevines in Iran
}

\author{
M. G. ZAMHARIR ${ }^{1}$, F. MOZAFFARIAN ${ }^{2}$ and A. HOSSEINI-GHARALARI ${ }^{3 *}$ \\ ${ }^{1}$ Plant Diseases Research Department, Iranian Research Institute of Plant Protection, \\ Agricultural Research, Education and Extension Organization (AREEO), Tehran, Iran \\ ${ }^{2}$ Insect Taxonomy Research Department, Iranian Research Institute of Plant protection, \\ Agricultural Research, Education and Extension Organization (AREEO), Tehran, Iran \\ ${ }^{3}$ Agricultural Entomology Research Department, Iranian Research Institute of Plant Protection, \\ Agricultural Research, Education and Extension Organization (AREEO), Tehran, Iran
}

(Received: 3 September 2018; accepted: 12 November 2018)

\begin{abstract}
Following recent detection of 'Candidatus Phytoplasma fraxini', ' $\mathrm{Ca}$. P. aurantifolia', ' $\mathrm{Ca}$. P. solani' and ' $C a$. P. phoenicium'-related strains in Iranian vineyards, a survey was conducted in 2016-2017 in vineyards located in Qazvin province of Iran. Nested PCR analysis was performed to identify phytoplasma strains in leafhopper species. The overall, less than $5 \%$ of grapevine trees shows phytoplasma symptoms and phytoplasma was detected in all symptomatic samples. Phytoplasma DNA was detected in two leafhopper species. Most leafhopper species in which phytoplasma DNA were detected are recorded to be grass feeders, among which, Stolbur phytoplasma vectors, i.e. Psammotettix alienus (Dahlbom 1851) and Agallia ribauti (Ossiannilsson, 1938), showed a strong potential ability for ' $\mathrm{Ca}$. P. solani' transmission in Qazvin vineyards. The possibility of phytoplasma transmission between leafhoppers and grapevines is discussed.
\end{abstract}

Keywords: Phytoplasma, leafhoppers, grapevine, decline, transmission.

The presence of phytoplasmas associated with yellows disease in Vitis vinifera L. in Iran was reported based on symptoms, nested PCR/RFLP detection or sequencing of 16Sr RNA gene. The phytoplasmas, identified so far, are 'Candidatus Phytoplasma solani'-related strains and more recently a strain enclosed in 16SrIX-C subgroup (Ghayeb Zamharir et al., 2017). Four different phytoplasmas ('Candidatus Phytoplasma fraxini', ' $C a$. P. aurantifolia', ' $C a$. P. solani' and ' $C a$. P. phoenicium) have been detected in Iranian vineyards that had grape decline symptoms. Among these phytoplasmas, ' $\mathrm{Ca}$. P. solani'-related strains were the most prevalent (Ghayeb Zamharir et al., 2017).

Phytoplasmas previously called mycoplasma-like organisms, are wall-less prokaryotes belonging to the class of mollicutes (McCoy et al., 1989; Lee et al., 2010). Phytoplasmas are transmitted by grafting, dodders and phloem-feeding insects, most of which are Auchenorrhyncha, such as leafhoppers (Schvester et al., 1961; Nault, 1990; Fernando et al., 1993; Olivier et al., 2012). The spread and progress of grape decline are influenced 
by inoculum density and activity of vectors. Therefore, information on potential vectors and their population dynamics, along with data on inoculum sources are needed for risk assessment and progress prediction of grape decline, which finally will end up in successful control methods (Weber and Maixner, 1998).

Detection of phytoplasma in insect vectors by molecular methods is a step toward identification of a vector, however, this does not provide a strong evidence of its vectoring ability, as many insects can acquire phytoplasmas and be considered as 'carriers' (Hogenhout et al., 2008). Meanwhile, some insect species can be competent 'vectors', i.e., can acquire phytoplasmas from a plant and successfully transmit them to another plant (Weintraub and Jones, 2009). Vectoring ability is the result of a successful specific tritrophic interaction between the phytoplasma, the insect vector and the host plant (Weintraub and Beanland, 2006; Hogenhout et al., 2008). Therefore, biological transmission assays are, the only way to ascertain phytoplasma transmissibility. These assays are time-consuming and require a big colony of phytoplasma-free insects and also phytoplasma-susceptible plants on which the insects shall feed and survive (Daire et al., 1992; Maixner et al., 1995; Sforza et al., 1998). Therefore, they are not practical for large-scale epidemiological studies (Gatineau et al., 2001).

Essential step to study phytoplasma disease in vineyards is to determine the biodiversity of leafhoppers associated with vineyards, and identify the phytoplasma strains associated with their potential insect vectors. The main objectives of this study were: 1) to detect phytoplasmas in leafhopper species that were collected from Iranian vineyards infected with grape decline, and 2) to identify phytoplasma strains present in these leafhoppers.

\section{Materials and Methods}

\section{Insect samples}

During 2016 and 2017, vineyards of Qazvin province (Iran) were visited at least once a month to select vineyards showing characteristic symptoms (e.g., yellowing and leaf scorch). Six commercial vineyards were selected in which yellow sticky traps $(20 \times 10 \mathrm{~cm})($ Russel Company, UK) were installed on vines branches at a height of $75 \mathrm{~cm}$ from ground. In each vineyard, five independent rows (one cultivar/row), with symptomatic grapevines were selected (Table 1).

Installation of sticky traps started on May. Sticky traps were collected fortnightly and new traps were replaced until September. Each collected trap was transferred to laboratory in a separate plastic bag, so the traps would not stick to each other. Traps were checked under stereomicroscope, and the leafhoppers were detached along with surrounding sticky card using a sharpe scalpel. The samples were transferred into xylene (dimethylbenzene) to dissolve the glue and release the leafhopper. The leafhoppers were kept in ethanol until identification, followed by molecular studies.

\section{Leafhopper identification}

Leafhopper species were identified according to the habitus characters and male genitalia, using original descriptions and published illustrations (Emeljanov, 1967; Dlabola, 1974; Biedermann and Niedringhaus, 2009). 
Table 1

The sources of each leafhopper population and the quantity of the insects belonging to each population

\begin{tabular}{|c|c|c|c|c|c|}
\hline Population no. & $\begin{array}{l}\text { Geog } \\
\text { of stu }\end{array}$ & $\begin{array}{l}\text { raphical coordinates } \\
\text { died gardens }\end{array}$ & Quantity of the insects & Year & Insect spices \\
\hline 1 & $39 \mathrm{~S}$ & $\begin{array}{l}381746 \\
3986603\end{array}$ & 10 & 2016 & P. shirazicus \\
\hline 2 & $39 \mathrm{~S}$ & $\begin{array}{l}381746 \\
3986603\end{array}$ & 15 & 2016 & A. ribauti \\
\hline 3 & $39 \mathrm{~S}$ & $\begin{array}{l}381746 \\
3986603\end{array}$ & 12 & 2016 & P. alienus \\
\hline 4 & $39 \mathrm{~S}$ & $\begin{array}{l}381558 \\
3986737\end{array}$ & 17 & 2016 & P. alienus \\
\hline 5 & $39 \mathrm{~S}$ & $\begin{array}{l}381558 \\
3986737\end{array}$ & 14 & 2016 & A. ribauti \\
\hline 6 & $39 \mathrm{~S}$ & $\begin{array}{l}381558 \\
3986737\end{array}$ & 10 & 2016 & P. shirazicus \\
\hline 7 & $39 \mathrm{~S}$ & $\begin{array}{l}381558 \\
3986737\end{array}$ & 15 & 2016 & P. shirazicus \\
\hline 8 & $39 \mathrm{~S}$ & $\begin{array}{l}380665 \\
3986734\end{array}$ & 14 & 2016 & P. alienus \\
\hline 9 & $39 \mathrm{~S}$ & $\begin{array}{l}380665 \\
3986734\end{array}$ & 15 & 2016 & P. shirazicus \\
\hline 10 & $39 \mathrm{~S}$ & $\begin{array}{l}382283 \\
3982474\end{array}$ & 17 & 2016 & A. ribauti \\
\hline 11 & $39 \mathrm{~S}$ & $\begin{array}{l}382283 \\
3982474\end{array}$ & 10 & 2016 & A. ribauti \\
\hline 12 & $39 \mathrm{~S}$ & $\begin{array}{l}382283 \\
3982474\end{array}$ & 14 & 2016 & P. shirazicus \\
\hline 13 & $39 \mathrm{~S}$ & $\begin{array}{l}381793 \\
3982038\end{array}$ & 17 & 2016 & P. alienus \\
\hline 14 & $39 \mathrm{~S}$ & $\begin{array}{l}381793 \\
3982038\end{array}$ & 22 & 2016 & A. ribauti \\
\hline 15 & $39 \mathrm{~S}$ & $\begin{array}{l}381793 \\
3982038\end{array}$ & 15 & 2016 & P. alienus \\
\hline 16 & $39 \mathrm{~S}$ & $\begin{array}{l}381746 \\
3986603\end{array}$ & 14 & 2017 & P. shirazicus \\
\hline 17 & $39 \mathrm{~S}$ & $\begin{array}{l}381746 \\
3986603\end{array}$ & 12 & 2017 & A. ribauti \\
\hline 18 & $39 \mathrm{~S}$ & $\begin{array}{l}381558 \\
3986737\end{array}$ & 14 & 2017 & A. ribauti \\
\hline 19 & $39 \mathrm{~S}$ & $\begin{array}{l}381558 \\
3986737\end{array}$ & 15 & 2017 & A. ribauti \\
\hline 20 & $39 \mathrm{~S}$ & $\begin{array}{l}382283 \\
3982474\end{array}$ & 17 & 2017 & P. alienus \\
\hline 21 & $39 \mathrm{~S}$ & $\begin{array}{l}380665 \\
3986734\end{array}$ & 20 & 2017 & A. ribauti \\
\hline 22 & $39 \mathrm{~S}$ & $\begin{array}{l}382283 \\
3982474\end{array}$ & 18 & 2017 & P. alienus \\
\hline 23 & $39 \mathrm{~S}$ & $\begin{array}{l}382283 \\
3982474\end{array}$ & 17 & 2017 & P. shirazicus \\
\hline 24 & $39 \mathrm{~S}$ & $\begin{array}{l}381793 \\
3982038\end{array}$ & 15 & 2017 & P. shirazicus \\
\hline 25 & $39 \mathrm{~S}$ & $\begin{array}{l}381793 \\
3982038\end{array}$ & 17 & 2017 & P. alienus \\
\hline
\end{tabular}




\section{DNA isolation}

DNA was extracted from insects according to Maixner et al. (1995). Insects tissue was ground in extraction buffer $(100 \mathrm{mMTrisHCl}$ at $\mathrm{pH} 8.0,2 \%$ cetyltrimethylammonium bromide (CTAB), 1.4 M NaCl, $20 \mathrm{mM}$ EDTA, and $0.2 \%$ 2-mercaptoethanol) at a ratio of 1:5 (wt/vol, tissue/buffer). The slurry was incubated for $20 \mathrm{~min}$ at $60^{\circ} \mathrm{C}$ and centrifuged for $10 \mathrm{~min}$ at $3,000 \times \mathrm{g}$. The supernatant was collected and extracted with an equal volume of chloroform/isoamyl alcohol $(24: 1, \mathrm{vol} / \mathrm{vol})$, followed by centrifugation and precipitation with 1 volume of isopropanol. Following 30-min incubation at $-20{ }^{\circ} \mathrm{C}$, the DNA was pelleted at $12,000 \times g$ for $30 \mathrm{~min}$. The pellet was washed twice with $70 \%$ ethanol and resuspended in $50 \mu 1$ of $10 \mathrm{mMTris}$ and $1 \mathrm{mM}$ EDTA at $\mathrm{pH} 8.0$ (TE).

\section{Nested PCR}

DNA extracts were diluted 1:10 with $10 \mathrm{mM}$ Tris- $\mathrm{Cl}, \mathrm{pH} 8.5$, and used as a template in PCR to amplify the $16 \mathrm{~S}$ rRNA-encoding gene F2nR2 fragment with primers $\mathrm{R} 16 \mathrm{~F} 2 \mathrm{n} / \mathrm{R} 16 \mathrm{R} 2$. In this order, PCR amplification with universal phytoplasma primers P1/ Tint (Deng and Hiruki, 1991; Smart et al., 1996) followed by R16F2n/R2, R16mF1/mR1 (Gundersen and Lee, 1996), R16(I)F1/R1 (Lee et al., 1994) or 6R758f/16R1232r (= M1/ M2) primers (Gibb et al., 1995) in nested polymerase chain reaction (PCR) assays using as template the PCR products was diluted with sterile distilled water (1:30).

\section{DNA sequencing and phylogenetic tree}

Selected R16F2n/R2 (1,248 bp) and M1/M2 amplified fragments from phytoplasma detected in grapevine leafhoppers were directly sequenced. Sequences were trimmed and compared with sequences of representative phytoplasma strains detected in grapevine with decline symptoms and other $16 \mathrm{Sr}$ phytoplasma groups (Wei et al., 2008) recorded in GenBank, using the BLAST Program (http://www.ncbi.nlm.nih.gov) and grouped into phylogenetic tree using the Mega7 Program (Tamura et al., 2011). Sequence alignments were performed, using Clustal X (Thompson et al., 1997). The sequences obtained from grapevine samples were then trimmed to the shortest one and employed in phylogenetic analyses using all the reported 'Candidatus Phytoplasma' species officially described using Acholeplasma laidlawii as the out group. The analysis was replicated 1,000 times to estimate stability and support for the inferred clades. The evolutionary history was inferred using the Neighbor-Joining method. The evolutionary distances were computed using the Maximum Composite Likelihood method and evolutionary analyses were conducted in MEGA6 (Tamura et al., 2013).

\section{Restriction fragment length polymorphism (RFLP) analyses}

For RFLP analysis $3 \mu \mathrm{l}$ (about $300 \mathrm{ng}$ of DNA) of R16F2n/R2 or M1/M2 PCR products of each positive nested PCR product was separately digested with enzymes (TrulI, TaqI, RsaI and Tsp509I) at $65^{\circ} \mathrm{C}$, as recommended by the manufacturers (Fermentas, Vilnius, Lithuania and New England Biolabs, respectively). Restricted fragments 
were separated through 3\% Agaros gel electrophoresis in TAE buffer. Patterns obtained were recorded in a Kodak gel documentation unit.

\section{Results}

\section{Leafhopper identification}

Three different leafhopper species were identified, as follows: Platymetopius shirazicus Dlabola 1974 (Hom.: Cicadellidae) (Fig. 1, Table 1), Agallia ribauti Ossiannilsson 1938 (Hom.: Cicadellidae) (Fig. 1) and Psammotettix alienus Dahlbom 1851 (Hom.: Cicadellidae) (Fig. 1). The species A. ribauti and P. alienus can transmit Stolbur phyroplasma.

\section{Detection and identification of phytoplasmas}

Among more than 25 leafhopper populations collected from Qazvin vineyards during 2016 and 2017, three species of three different genera were identified and submitted to PCR analysis. Phytoplasma DNA was detected in seven samples belonging to A. ribauti and $P$. alienus species.

RFLP analysis of the R16F2n/R2 and M1/M2 products with TaqI and MseI (Fig. 2) indicated that the phytoplasmas from grapevine leafhoppers in Qazvin province (Iran) are mixed infection of two different group 16SrII ('Candidatus Phytoplasma aurantifolia') and 16SrXII group (Ca. P. solani', “stolbur”) (Fig. 2). But single infection was observed in three populations of seven positive populations that related to A. ribauti species. Sequencing and blast analysis of these samples indicated that this phytoplasma related to the 16SrII ('Candidatus Phytoplasma aurantifolia') group and shared 100\% similarity
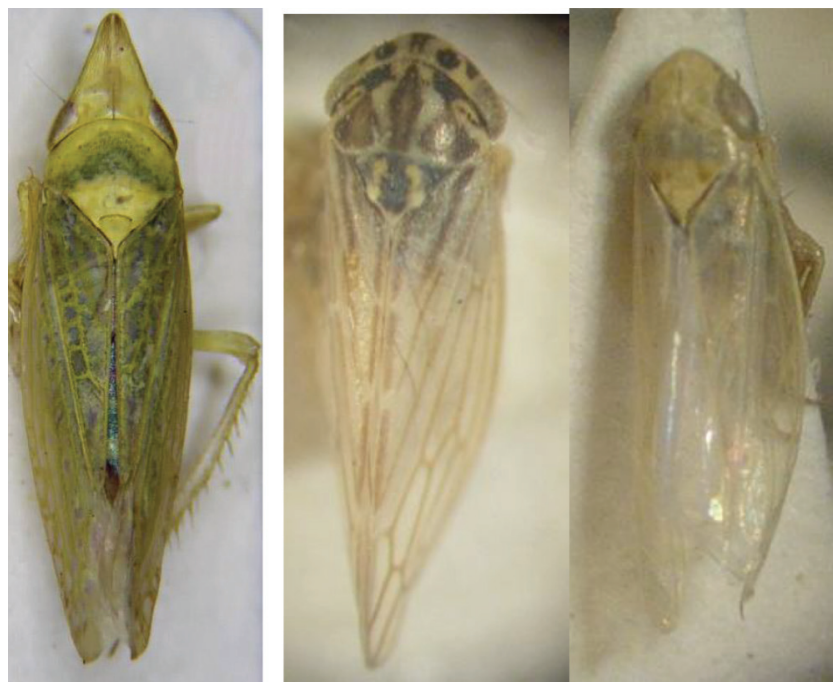

Fig. 1. Platymetopius shirazicus Dlabola, 1974, Agallia ribauti Ossiannilsson, 1938, Psammotettix alienus (Dahlbom, 1850) 


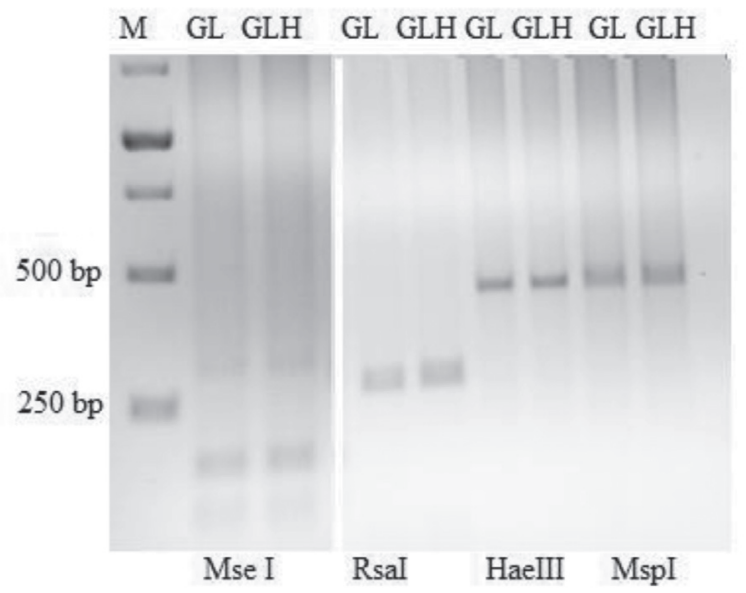

Fig. 2. M1/M2 RFLP analysis of phytoplasma collected from grape leaf (GL) and leafhoppers $(\mathrm{GLH})$ in vineyards

with phytoplasma isolate that have been collected from grape vine decline in this area (accession numbers MH342005 and MH342006). The sequence of phytoplasma isolates that amplifies from grapevine leafhoppers in Qazvin province deposited in gene bank (NCBI) as MH342002, MH342003 and MH342004 accession numbers. Phylogenetic analysis also clustered grapevine leaf and leafhoppers phytoplasma strains with 16SrII phytoplasma group (Fig. 3).

\section{Discussion}

Phytoplasmas are important insect transmitted pathogens attack more than hundreds of commercial and native plants, causing minor to extensive damage (Kirkpatrick, 1992; Davies et al., 1992; Lee et al., 1996, 2010). Insect vectors of phytoplasma diseases including primarily leafhoppers, planthoppers, and psyllids, have been identified for relatively few phytoplasma diseases (Kirkpatrick, 1992; Davies et al., 1992; Maixner, 2010).

Surveys of insects found on and around affected plants and focusing on the phloem-feeding Hemiptera taxa are the first step towards determining vectors of a given phytoplasma disease (Davies et al., 1992). In this order in this study we have collected leafhoppers in Iranian vineyard that have been infected by phytoplasma disease.

Grape decline and yellows phytoplasma disease is one of important phytoplasma disease in all over the world (Sforza et al., 1998; Rott et al., 2007; Quaglino et al., 2013) that is an emerging threat to vineyards in Iran. The extensive survey on phytoplasma detection and identification in Iran vineyards indicated the presence of 'Candidatus Phytoplasma fraxini', 'Ca. P. phoenicium', ' $C a$. P solani' and ' $C a$. P. aurantifolia'- related strains (Ghayeb Zamharir et al., 2017). The presence of these phytoplasmas is probably related to the presence of those in the Iranian plants and trees, however the work about grapevine phytoplasma insect vectors of all the phytoplasmas detected in Iran vineyards is not studied yet (Ghayeb Zamharir et al., 2017). 
Three leafhopper species including $P$. shirazicus, A. ribauti and P. alienus were collected from Qazvin province (Iran). P. shirazicus was recorded as a pest on almond with mild economic importance by Rajabi (1991). The species is known as an endemic species to Iran, distributed in central Alborz mountain and southwest of the country (Mozaffarian and Wilson, 2016). Due to the lack of any report on the serious damage of the species, it was suggested by Mozaffarian (2018) to evaluate the real pest status of the

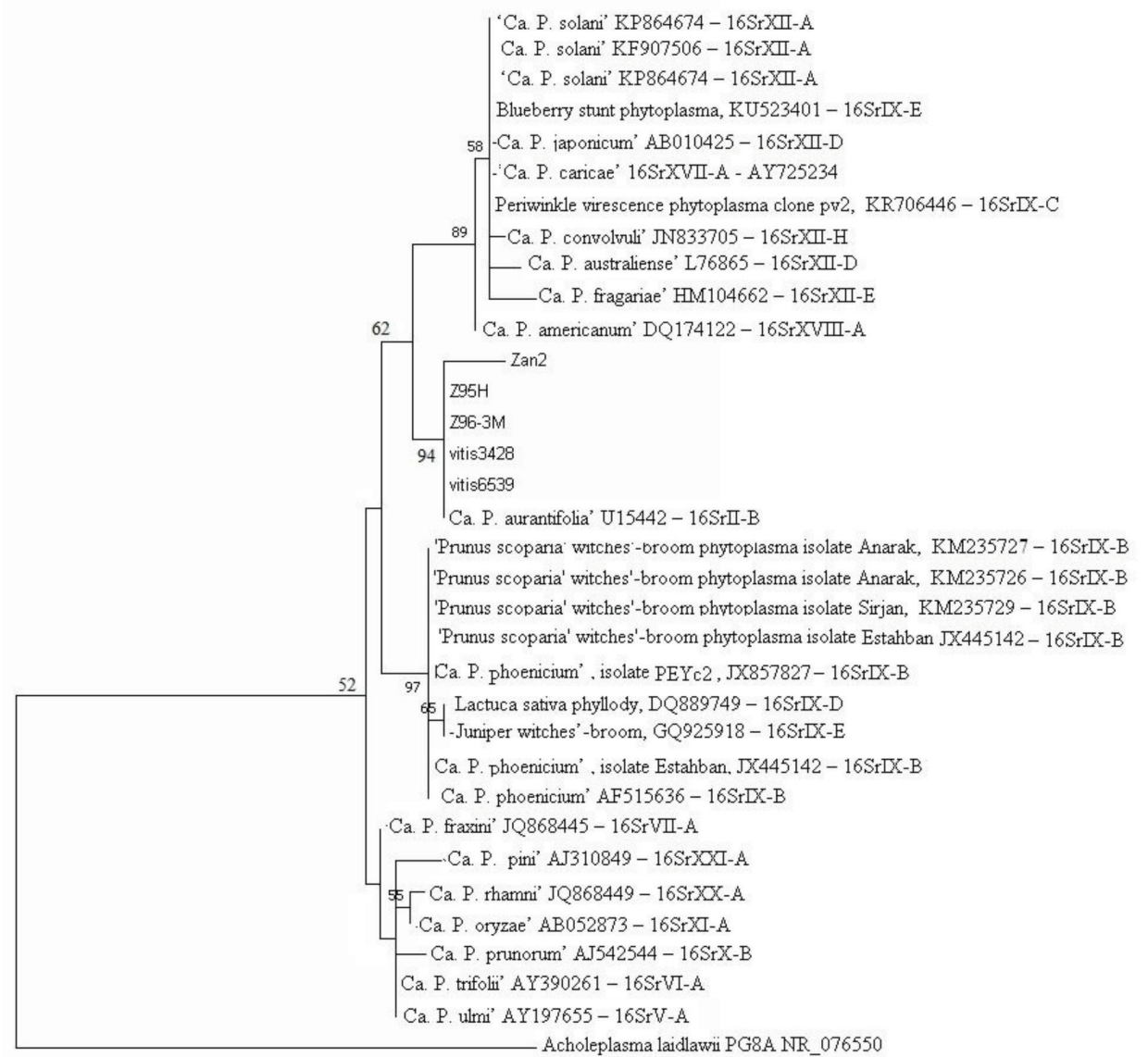

0.050

Fig. 3. Molecular Phylogenetic analysis by Maximum Likelihood method. The evolutionary history was inferred by using the Maximum Likelihood method based on the Tamura-Nei model.

The tree with the highest log likelihood (-476.95) is shown. The percentage of trees in which the associated taxa clustered together is shown next to the branches. Initial tree(s) for the heuristic search were obtained automatically by applying Neighbor-Join and BioNJ algorithms to a matrix of pairwise distances estimated using the Maximum Composite Likelihood (MCL) approach, and then selecting the topology with superior log likelihood value. The tree is drawn to scale, with branch lengths measured in the number of substitutions per site. The analysis involved 34 nucleotide sequences. Codon positions included were $1 \mathrm{st}+2 \mathrm{nd}+3 \mathrm{rd}+$ Noncoding. All positions containing gaps and missing data were eliminated.

There were a total of 126 positions in the final dataset. Evolutionary analyses were conducted in MEGA7 (Tamura et al., 2004) 
species more thoroughly. Among the collected leafhoppers, only A. ribauti and P. alienus species were PCR assay positive. A. ribauti was already recorded by Kheyri (1989) as a pest with minor economic importance on the leaves of sugar-beet in Iran. In other parts of the world, A. ribauti was shown to be able to transmit stulber phytoplasma to Vicia faba seedlings and also positive to those phytoplasmas on carrot (Drobnjaković et al., 2010). Kheyri (1989) mentioned P. alienus as a pest with little economic importance on leaves of sugar-beet. The species is known as s phloem-feeding vector in vineyards of Italy (Minuz et al., 2013). Drobnjaković et al. (2010) detected stolbur phytoplasmas in the specimens of this species. Landi et al. (2013) showed the inoculation of the species to phytoplasma 16SrI-B subgroup. Result of RFLP analysis shows that four out of seven leafhopper population collected from Qazvin vineyards had mixed infection of "stolbur" with 16SrII ('Candidatus Phytoplasma aurantifolia'). In order to lack of sequencing data for stolbur phytoplasma associated with vineyards leafhoppers, its impossible to confirm that association phytoplasma is causal agent of grape yellows and decline or not. But sequencing and blast analysis of phytoplasmas that were detected in A. ribauti species indicated that a phytoplasma related to the $16 \mathrm{SrII}$ ('Candidatus Phytoplasma aurantifolia') group (accession numbers MH342005 and MH342006) shared 100\% similarity with grape decline phytoplasma isolates (accession numbers MH342002, MH342003).

Recently studies in the field of biology, ecology, vector relationships, and epidemiology of phytoplasma diseases has gone into understanding individual phytoplasma diseases and their vectors. But many questions about phytoplasma plant disease-vector relationships is unsolved yet (Lee et al., 1996, 2010; Maixner, 2010) that could limit the capacity of managers to make informed decisions to protect crops and endangered indigenous plants. These results demonstrate the putative vectors of grape decline and yellows phytoplasma disease that can help to perform the transmission tests and understand grape phytoplasma pathosystems.

\section{Literature}

Biedermann, R. and Niedringhaus, R. (2009): The Plant and Leafhoppers of Germany. Identification Key to All Species. Wilhelm Brüggemann GmbH, Bremen, 409 p.

Daire, X., Boudon-Padieu, E. and Bervillé, A. A. (1992): Cloned DNA probes for detection of grapevine Flavescencedoree mycoplasma-like organism (MLO). Ann. Appl. Biol. 121, 95-103.

Davies, D., Guise, C., Clark, M. and Adams, A. (1992): Parry's disease of pears is similar to pear decline and is associated with mycoplasma-like organisms transmitted by Cacopsylla pyricola. Plant Pathol. 41, 195-203.

Deng, S. and Hiruki, C. (1991): Amplification of 16S rRNA genes from culturable and nonculturable Mollicutes. J. Microbiol. Methods 14, 53-61.

Dlabola, J. (1974): Ergebnisse der Tschechoslowakisch-Iranischen Entomologischen Expedition nach dem Iran, 1970, No. 3 (Homoptera: Auchenorrhyncha) (1 Teil). Acta Entomologica Musei Nationalis Pragae, Supplement 6, 29-73.

Drobnjaković, T., Perić, P., Marčić, D., Picciau, L., Alma, A., Mitrović, J., Duduk, B. and Bertaccini, A. (2010): Leafhoppers and Cixiids in phytoplasma-infected carrot fields: Species composition and potential phytoplasma vectors. Pesticides and Phytomedicine, Belgrade, 25, 311-318.

Emeljanov, A. F. (1967): Suborder Cicadinea (Auchenorrhyncha). In: G. Ya. Bei-Bienko (ed.): Keys to the Insects of the European USSR. Israel Program for Scientific Translations, Jerusalem, pp. 421-551.

Fernando, E. V., Davis, R. E., Barbosa, P., Dally, E. L., Purcell, A. H. and Lee, 1-M. (1993): Detection of a plant pathogen in a nonvector insect species by the polymerase chain reaction. Phytopathology 83, 621-624. 
Gatineau, F., Larrue, J., Clair, D., Lorton, F., Richard-Molard, M. and Boudon-Padieu, E. (2001): A new natural planthopper vector of stolbur phytoplasma in the genus Pentastiridius (Hemiptera: Cixiidae). Eur. J. Plant Pathol. 107, 263-271.

Ghayeb Zamharir, M., Shokrollah, H., Samanta, P. and Assunta, B. (2017): Identification and characterization of phytoplasma related to group II associate with grape decline in Iran. Molecular identification of diverse 'Candidatus Phytoplasma' species associated with grapevine decline in Iran. J. Phytopathology 165, 407-413. doi.org/10.1111/jph.12574.

Gibb, K. S., Padovan, A. C. and Mogen, B. D. (1995): Studies on sweet potato little-leaf phytoplasmas detected in sweet potato and other species growing in Northern Australia. Phytopathology 85, 169-174.

Gundersen, D. E. and Lee, I.-M. (1996): Ultrasensitive detection of phytoplasmas by nested-PCR assays using two universal primer pairs. Phytopathologia Mediterranea 35, 144-151.

Hogenhout, S. A., Oshima, K., Ammar, E.-D., Kakizawa, S., Kingdom, H. N. and Namba, S. (2008): Phytoplasmas: bacteria that manipulate plants and insects. Mol. Plant Pathol. 9, 403-423.

Kheyri, M. (1989): An inventory of pests attacking sugar-beet in Iran. Appl. Entomol. and Phytopathol. 56, 75-91 [In Persian with English summary].

Kirkpatrick, B. C. (1992): Mycoplasma-like organisms-plant and invertebrate pathogens. In: A. Balows, H. G. Truper, M. Dworkin, W. Harder and K.-H. Schleifer (eds): The Prokaryotes. Springer, New York, 4, 4050-4067.

Landi, L., Isidoro, N. and Riolo, P. (2013): Natural phytoplasma infection of four phloem-feeding Auchenorrhyncha across vineyard agroecosystems in Central-Eastern Italy. J. Econ. Entomol. 106, 604-613.

Lee, I.-M., Gundersen, D. E., Hammond, R. W. and Davis, R. E. (1994): Use of mycoplasma-like organisms (MLO) group-specific oligonucleotide primers for nested PCR assays to detect mixed-MLO infections in a single host plant. Phytopathology 84, 559-566.

Lee, I.-M., Danielli, A., Bertaccini, A., Vibio, M. and Bartoszyk, I. M. (1996): Multiple phytoplasmas detected in two species of Homoptera feeding on pear trees with decline symptoms. Int. Org. Mycoplasmol. Lett. 4, 199.

Lee, I. M., Bottner, K. D., Zhao, Y., Davis, R. E. and Harrison, N. A. (2010): Phylogenetic analysis and delineation of phytoplasmas based on SecY gene sequences. Int. J. Syst. Evol. Microbiol. 60, 2887-2897.

Maixner, M., Ahrens, U. and Seemüller, E. (1995): Detection of German grapevine yellows (Vergilbungskrankheit) MLO in grapevine, alternative hosts and vector by a specific PCR procedure. Eur. J. Phytopathol. $101,241-250$.

Maixner, M. (2010): Phytoplasmas epidemiological systems with multiple plant hosts. In: P. G. Weintraub and P. Jones (eds): Phytoplasmas: Genomes, Plant Hosts and Vectors. CABI Publishing, Wallingford, UK, 213-232.

McCoy, R. E., Caudwell, A., Chang, C. J., Chen, T. A. et al. (1989): Plant diseases associated with mycoplasmalike organisms. In: R. F. Whitcomb and J. G. Tully (eds): The Mycoplasmas. Spiroplasmas, Acholeplasmas and Mycoplasmas of Plant and Arthropods. Academic Press, New York, Vol. 5, pp. 545-640.

Minuz, R. L., Isidoro, N., Casavecchia, S., Burgio, G. and Riolo, P. (2013): Sex-dispersal differences of four phloem-feeding vectors and their relationship to wild-plant abundance in vineyard agroecosystems. J. Econ. Entomol. 106, 2296-2309.

Mozaffarian, F. and Wilson, M. R. (2016): A checklist of the leafhoppers of Iran (Hemiptera: Auchenorrhyncha: Cicadellidae). Zootaxa 4062, 1-63.

Mozaffarian, F. (2018): An identification key to the species of Auchenorrhyncha of Iranian fauna recorded as pests in orchards and a review on the pest status of the species, Zootaxa 4420, 475-501.

Nault, L. R. (1990): Evolution of an insect pest: Maize and the com leafhopper, a case study. Maydica 35, $165-175$.

Olivier, C. Y., Vincent, C., Saguez, J., Galka, B., Weintraub, P. G. and Maixner, M. (2012): Leafhoppers and planthoppers: their bionomics, pathogen transmission and management in vineyards. In: N. J. Bostanian, C. Vincent and R. Isaacs (eds): Arthropod Management in Vineyards: Pests, Approaches and Future Directions. Springer, Dordrecht, The Netherlands, pp. 253-270.

Quaglino, F., Zhao, Y., Casati, P., Bulgari, D., Bianco, P. A., Wei, W. and Davis, R. E. (2013): 'Candidatus Phytoplasma solani', a novel taxon associated with stolbur- and Bois noir-related diseases of plants. International J. Systematic and Evolutionary Microbiology 63, 2879-2894. 
Rajabi, Gh. (1991): Insects attacking rosaceous fruit trees in Iran. Homoptera. Ministry of Agriculture, Tehran, Vol. 3, 256 p.

Rott, M., Johnson, R., Masters, C. and Green, M. (2007): First report of bois noir phytoplasma in grapevine in Canada. Plant Disease, 91, 1682.

Schvester, D., Carle, P. and Mouttous, G. (1961): Sur la transmission de la Flavescencedorée des vignes par unecicadelle. C. R. Acad. Agric. 47, 1021-1024.

Sforza, R., Clair, D., Daire, X., Larrue, J. and Boudon-Padieu, E. (1998): The role of Hyalesthesobsoletus (Hemiptera: Cixiidae) in the occurrence of Bois noir of grapevine in France. J. Phytopathol. 146, 549-556.

Smart, C. D., Schneider, B., Blomquist, C. L., Guerra, L. J., Harrison, N. A., Ahrens, U., Lorenz, K. H., Seemülle, E. and Kirkpatrick, B. C. (1996): Phytoplasma-specific PCR primers based on sequences of the 16-23S rRNA spacer region. Appl. and Environ. Microbiol. 62, 2988-2993.

Tamura, K., Nei, M. and Kumar, S. (2004): Prospects for inferring very large phylogenies by using the neighbor-joining method. Proc. of the National Academy of Sciences (USA) 101, 11030-11035.

Tamura, K., Peterson, D., Peterson, N., Stecher, G., Nei, M. and Kumar, S. (2011): MEGA5: molecular evolutionary genetics analysis using maximum likelihood, evolutionary distance, and maximum parsimony methods. Mol. Biol. Evol. 28, 2731-2739.

Tamura, K., Stecher, G., Peterson, D., Filipski, A. and Kumar, S. (2013): MEGA6: Molecular Evolutionary Genetics Analysis version 6.0. Molecular Biology and Evolution 30, 2725-2729.

Thompson, J. D., Gibson, T. J., Plewniak, F., Jeanmougin, F. and Higgins, D. G. (1997): The CLUSTAL X windows interface: flexible strategies for multiple sequence alignment aided by quality analysis tools. Nucleic Acids Research 25, 4876-4882.

Weber, A. and Maixner, M. (1998): Survey of populations of the planthopper Hyalesthesobsoletus Sign. (Auchenorrhyncha: Cixiidae) for infection with the phytoplasma causing grapevine yellows in Germany. J. Appl. Entomol. 122, 375-381.

Wei, W., Lee, I.-M., Davis, R. E., Suo, X. and Zhao, Y. (2008): Automated RFLP pattern comparison and similarity coefficient calculation for rapid delineation of new and distinct phytoplasma $16 \mathrm{Sr}$ subgroup lineages. Int. J. Syst. Evol. Microbiol. 58, 2368-2377.

Weintraub, P. G. and Beanland, L. (2006): Insect vectors of phytoplasmas. Annu. Rev. Entomol. 51, 91-111.

Weintraub, P. G. and Jones, P. (2009): Phytoplasmas: Genomes, Plant Hosts and Vectors. CABI, Wallingford, 352 p. 